\title{
State Building, States, and State Transformation in Africa: Introduction
}

\section{Carol Ijeoma Njoku}

University of Nigeria, Enugu Campus

\author{
Dmitri M. Bondarenko \\ Institute for African Studies, Russian Academy \\ of Sciences, Moscow
}

Postcolonial societies are a unique event in world history. Their emergence in the mid-twentieth century did not result from centuries-old internal social processes, but was directly determined by the formation and short-lived (by historical standards) existence and disintegration of the European colonial empires. The colonial borders reflected primarily the balance of forces between the metropolitan powers in this or that region, but not the preceding course of the region's own political, social, economic, and cultural history. With rare exceptions, many different peoples were forcibly united within a colony. Not only kinship but also cultural affinity among those peoples was often absent. At the same time, the colonial borders would divide one people or break the historically established regional systems of economic and cultural ties not less infrequently. Likewise, the colonialists would forcibly unite peoples that had never formed regional political and economic systems; moreover, had different levels of sociocultural complexity, and sometimes did not even know about each other or were historical enemies. At the same time, the colonial borders would often separate historically and economically connected peoples and societies. These features were supplemented by stadial and civilizational heterogeneity of the colonial societies. The elements of capitalism, implanted by the Europeans in different spheres, did not synthesize with a set of pre-capitalist features of the local societies. There was also a little intersection between the autochthonous and new sectors of public life, in which essentially different value systems dominated.

Social Evolution \& History, Vol. 17 No. 1, March 2018 3-15

(C) 2018 'Uchitel' Publishing House

DOI:10.30884/seh/2018.01.01 
The artificial complexity of cultural and societal composition, stadial and civilizational heterogeneity remained the fundamental features of most colonial societies throughout their existence. These were inherited by the postcolonial societies together with the colonial borders. Postcolonial states are the legacy of colonialism in the sense that when the colonizers were leaving, the world was already 'global'. As a matter of fact, it became such due to the Europeans' endeavors since the Age of Discoveries - 'the West's heroic deed', in Fernand Braudel's words (1986: 428-440). The sovereign nation-state is a form of political organization allowing a country to be a full subject of current international law. It is so because contemporary international law is based on recognition of the nation-state as the basic unit of international relations and world politics. Thus, the postcolonial countries simply had no alternative to declaring themselves sovereign nationstates.

In the postcolonial period the problems born by colonialism have acquired new dimensions, connected, in particular, with the necessity to substitute colonial states with sovereign nation-states. Respectively, the formation of national unity, when national identity would be more important for the citizens than belonging to any smaller group (regional, ethnic, religious, etc.), has become an important task. In Europe, it took centuries for realization of internal prerequisites for ripening of the nation as a form of cultural unity in the civil society and of the nation-state as a form of its political organization. As a result, in nation-states the cultural and political borders were brought into conformity (Gellner 1983) while the formation of civil society would bridge the gap between society and state (Breuilly 1993, 2005). In most postcolonial states, it became necessary to form civil societies, nation-states, and national cultures as fast as possible on the basis of in many ways random and heterogeneous conglomerate of cultures and societies. Note also that nation and nation-state are essentially European phenomena, in the sense that internal dynamics of the African and Asian societies did not push them in that direction. Many postcolonial states are still groping for a way to internal organicity, and to socio-cultural, national integrity.

Thus, the peculiar characteristics of society and state in postcolonial countries are a consequence of their unique formation pattern. They began to form during the colonial period and that is why reproduced the forms of political institutions and legal norms of the Modern-Time West. However, the postcolonial state could not internalize automatically their content, attached by the civil society that rose independently in Europe but not in Africa or Asia (Bondarenko 2014). 
The most significant feature of nation-building in postcolonial countries is the initially leading role of the state, not society. The civil society was not formed in African and Asian countries in the colonial period, thus, making the society's self-integration into nation impossible and only the state could take on the integrating role. Thus, nationbuilding in postcolonial countries was initiated and directed by an external to the society force that stood over it. This determines the specific character both of the process and of current results of postcolonial nation-building. In particular, it explains why there remains a significant gap between society and the state, why the impact of the former on the latter is insufficient. At the same time, the postcolonial state has turned out much more stable and capable of adapting to changes at the global, regional, and national levels than the scholars used to suppose just a decade ago (see Nugent 2011; Young 2012; Jakwa 2017). Although the formation of the civil society institutions and the increase in their role in recent decades is an indisputable fact in many African and Asian countries, the central role of the state in them, its priority over social and economic institutions (i.e., the ability not just to serve and direct, but also shape them and the very system of social relations) usually preserves. Without internal preconditions for the formation in the present borders and having an originally Modern European political system, the postcolonial countries more and more often can remain viable only with a considerable (compared to the liberal West) role of the state, including its 'constructivist' role in nation-building.

So, the real problem of most postcolonial countries is not that the role of the state in them is much bigger and more decisive than in the West. Their real problem is that the postcolonial states often turn out ineffective in terms of their own historical and socio-cultural logic (Chabal and Skalník 2010). Sixty years after the end of colonialism in Africa, the prototype of Africa's postcolonial states remains unsuccessful, lacking relevance, legitimacy, and delivery. When compared with the pan-European world, the trajectory of state building in Africa is peculiar and almost uniform. Generally, Africa's contemporary states are dysfunctional, insecure and fragile. The dismal records consist of violent conflicts, political, economic, ethnic identity crises that undermine the construction of a stable state. Such resurgence of conflicts manifests itself in different humanitarian disasters, and breakdown of political authority, as those recorded in Nigeria, Rwanda, Sudan, South Sudan, Sierra Leone, Somalia, Côte d'Ivoire, Burundi, Liberia, and the Democratic Republic of Congo. These depict failed attempts in state building. Such track records of conflicts and instabil- 
ity are often blamed on the weak structures of colonial legacies and western interventions in African political and economic development (Davis and Kalu-Nwiwu 2001: 1-11; Ejiogu 2011: 2-15). There are, however, other divergent views to these, referring to Roland Paris (2004), Jason Brownlee (2005, 2010), and Mathew L. Norman (2012: 173). Notwithstanding the contradicting opinions on the Western impacts on Africa's convoluted problems, the almost six decades of selfruling in Africa can be judged to be unfulfilling because of failed attempts to meet citizens' expectations of civil and political rights, social and economic rights, security, stability, political transparency, and accountability that form the benchmarks of successful democracy.

The lack of functional democracy has subverted socio-economic development and dashed the hopes for independence. The Africans, in different states, are yet to realize their full citizenship rights and inclusive government that can accommodate group identities within a sovereign state. More than half of African population live on less than one US dollar a day, and as of May 2016, of 48 states which the United Nations recognized as 'least developed countries' 33 were African ones (UN-OHRLLS 2016). In most African states, the citizens are denied their basic social and economic rights such as nutritional needs, water, shelter, health care, security, electricity, education, and good roads. Given their low incomes and the non-functional political structures, the masses struggle to meet these needs, and mostly end up through hardships and vulnerability. Failure to meet the rudimentary human needs engenders poverty and exposes people to greater social deprivation and insecurity (Nzongala-Ntalaja 2006: 71). Amilcar Cabral described similar state institutions as a defeat of the peoples' purpose for liberation struggle and independence. He thus argued:

The people struggle and accept the sacrifices demanded by the struggle, but in order to gain material advantages, to be able to live a better life in peace, to see their lives progress and to ensure their children's future. National liberation, the struggle against colonialism, working for peace and progress - independence - all these are empty words without meaning for the people, unless they are translated into a real improvement in standards of living. It is useless to liberate an area, if the people of that area are left without the basic necessities of life (Cabral 1979: 241).

The citizens' struggle for freedom is actualized only when the desired independence translates into socio-economic liberty that guarantees security of citizens' lives, dignity, and economic rights. Jacob Ade 
Ajayi (1982: 1-6) affirms Cabral's position, asserting that the fight for decolonization and political freedom presupposes a demand for a better life, which compels ordinary Africans to join in the anti-colonial freedom to end colonial exploitations and improve their conditions of lives. But ironically, the end of colonialism opened new windows for exploitation of Africans by Africans. Despite the paradox of poverty eradication and Millennium Developmental Goal (MDG) that set priority operational goals for African governments for 2015 and the political rhetoric for sustainable development, many Africans are exposed to poverty, social and economic deprivation, insecurity and human rights abuses. Notwithstanding these, the same victims are expected to live up to their civic responsibilities in a government where their expectations and aspirations are sacrificed on the altar of partisan interest. The unfulfilled promises, unsatisfied expectations coupled with blatant impunity of corrupt leaders provoke different forms of agitations and antagonism for freedom, autonomy and self-determination. In most cases, ethnic, religious, or political interest groups fuel such tensions, as in the cases of Sudan, Eritrea, Nigeria, etc.

The crisis of social identity is another challenging issue confronting state building in Africa. Social identity is not a natural phenomenon but is historically constructed; and as such can change with political transformation (Nzongala-Ntalaja 2006: 75). The ability to accommodate such socio-political change is the mark of civilization and authentic democracy. Where group identities are used to increase the manipulations of competitive partisan interest, and polarization of ethnic/tribal, religious, gender and class ideologies, the state institution is bound to collapse. Unfortunately, the conflict of exclusion and polarized politics, that is common in most African societies, has continuously held the practice of true democracy in hostage. Such identity conflicts as seen between ethnic and religious sects like Christians and Moslems; the Igbo, Hausa and Yoruba in Nigeria; the Arab Sudanese and Black Sudanese; the Rwandan Hutu and the Tutsi, saying the least, are contributory factors that undermine the state project. A statebuilding project that is premised on exclusion and social fragmentations is bound to reproduce division, sectarianism and conflicts that destroy legitimacy and authentic democracy.

The task of nation building requires an active process that involves both the leader and the people in effective collaborative actions to rebuild the core values of accommodation, respect of group and national identity, and the sense of belonging. These are based on shared values, tradition, history and aspirations. Africa's core values of 'live and let live' respect of peoples' lives, rights and dignity form 
their foundation of national identity, democracy and social cohesion. After these are established, the state institutions of democracy - laws, court system, law enforcement mechanisms, and the executive arms of government - can thrive to meet citizens' best expectations and delivery. These can only function when citizens are allowed to participate in governance by choosing their leaders, play active role in government policies and decision making. Freedom of press and judiciary, public opinion and participatory government are indices of functional democracy. Their lack is preconditions for conflicts, insecurity and violence, as it has been the case in most parts of Africa.

In the twenty-first century, the expectations and challenges of state building are enormous with the imposed demands of globalization. Unfortunately, the postcolonial African states have neither lived up to the desired standard in state building nor "transformed the inherited structures of the state and economy to serve the deepest aspirations of the peoples as opposed to the interests of the dominant classes of the world system, with which these rulers tend to identify' (Nzongala-Ntalaja 2006: 71; see also Norman 2012: 174-190). The deficiencies are exacerbated with the demands on African market and economy, which increasingly suffer from pressures of the world powers and international financial institutions' policy. To analyze these imperatives, Nzongala-Ntalaja's critical approach to these issues is necessary. In his response to Claude Ake's article 'Why Africa is Not Developing' (Ake 1985: 15), he provides a two-fold argument. First, he associates Africa's lack of development with internal factors such as corruption manifested in coveting public fund and privatization of government institutions by the leaders and their agents to impoverish the government and destabilize its major institutions that deliver dividends to the people (Nzongala-Ntalaja 2006: 77). When the state machineries are demobilized, development becomes impossible. On the other hand, the lack of development, as Nzongala-Ntalaja (2006: 78) argues, 'is a function of Western development strategies whose main achievement has been to further integrate African rulers into the international networks of wealth and privilege rather than to promote development and democracy.' The latter reiterates Cabral's conceptualization of Western globalization as calculated strategies to 'destroy the economy of the enemy and build our own economy' (Cabral 1979: 136). When African leaders abandon their homegrown values and strategies in pursuit western globalization, the outcome is what Frantz Fanon (1963: 178) described as 'permanent wish for identification' in the name of globalization, that results in 'tragic mishaps' and 'cracks in the edifice' in Africa's state building. The over-dependence on the West in terms of growth, 
production, importation, market, and even funding has worked effectively to destroy state building and pan-Africanism.

Several scholars and critics have addressed these dilemmas facing state building in Africa, such as Fanon (1963), Kirk-Greene (1971), Cabral (1979), Ake (1985), Ajayi (1982), and Ejiogu (2011). These scholars diagnosed challenges of state building mainly from colonial and anti-colonial perspectives without inclusive introspection into the indices of failed democracy. Several other arguments on the precarious state building referring to Paris $(1997,2004)$, Brownlee (2005), Verena Fritz and A. R. Menocal (2007), and David Chandler (2006) failed in introspective and comprehensive diagnosis of Africa's problems. They explore the consequences of colonialism and the Western influences in Africa's economic politics and history without critical analysis of the systemic factors caused by weak and fragile structures of the postcolonial African states. They lacked the introspective insight in postcolonial issues that undermine the efforts to sustainable democracy in Africa. Cabral (1979) and Nzongala-Ntalaja (2006) took a leap further in suggesting homegrown solutions to African state building, but they failed to provide workable initiatives on how these could be realized. The present work fills the void by rehashing the internally driven, dynamic, and developmental processes of rebuilding African states through consolidation of the social, economic, and political institutions that form the hallmark of a true democracy.

The present study explores the challenges of state building from multi-disciplinary perspectives: the growth and challenges of the African states; the government's role in managing state resources; the impacts of state's institutions; growth and sustainability. The research examines the actions and inactions of state leaders and the new paradigm of postcolonial imperialism that manifests itself through exploitation, corruption and lack of accountability. The debilitating effects of political ineptitude and the manipulation of such inefficiencies with ethnic/tribal and religious propaganda often create a water-shield for covering the impunities of corrupt leaders. This project examines how these entwine with the handling of different kinds of state conflicts that are driven along regional lines to destroy the growth of democracy and true nationalism. We explore their far-reaching consequences to state building and in addition proffer solutions to rebuilding African states through homegrown strategies that promote pan-Africanism rather than the blind pursuit of Western alternatives.

In the first decades of their independence many African states sought to implement the so-called 'catch-up development model,' that is to create an economic system similar to that of the developed countries. 
This model did not justify itself: while the postcolonial countries tried to industrialize, the First World was already becoming postindustrial, and the gap between it and the Third World was only growing. Likewise, in the postcolonial states, the task of nation-building modeled on the European nations of the Modern Time was and continues to be set, despite immense difficulties, explained, besides all the rest, by differences between the European and African (and Asian) traditional political cultures, social institutions, value systems and so on. However, today, in the West itself, they have to try to move away from the concept of the nation established by the end of the eighteenth century, first of all due to the French revolution (see, e.g., Dann and Dinwiddy 1988; Bell 2001; Keitner 2007). Now the Western states have to seek solutions to a completely different problem - of supporting their citizens' unity at preservation of cultural diversity brought by migrants from all over the world. Not a single cultural identity based on a single value system and dominating over local and particular identities, but equitable coexistence of many cultural identities is accentuated nowadays as a new basic national value, as a source of national development in the present conditions of intensive globalization. Respectively, globalization - socio-cultural, political, and economic - questions the future of the nation-state as a form of political organization and of the concept of sovereignty as the foundation of its legitimacy. It should not be overlooked that the nation-state is a historical event, what it means that it appears in specific historical conditions and disappears with their change. In the form in which the nation-state is known to now, it formed in Europe and North America in the Modern Time and flourished in the nineteenth and twentieth centuries, being adequate to the realities of the world of industrial capitalism and cultural nationalism. Other trends, related to globalization and postindustrialism, dominate in the world nowadays. Not surprisingly, the Modern-Time European concept of sovereignty as the main attribute of a nation-state, that sees a separate nation-state as the basic unit of international relations, is in crisis, too (see Turner 2004: 94-97; Kapferer and Bertelsen 2012: 29-94, 163-304). The creation of the European Union in 1993 became the first attempt (with still an unclear result) to endow transnational institutions the supreme sovereignty (and not to create a union of sovereign states, like the United Nations, the African Union and so forth). Evidently, in the postindustrial and postmodern world, we will see the birth of the post-nation-state, based on refusal from national sovereignty (but not independence) as the state's main attribute in favor of trans-state governance institutions. In parallel, a global transnational culture will be forming, that will not 
abolish but unite national cultures. At this, cultural nationalism is losing congruence to patriotism: similar to national patriotism, it praises devotion to co-citizens as people of the same culture and value system, while nowadays co-citizenship does not presuppose inevitably such a unity. That is why citizenship is becoming more and more a legal category, gradually losing cultural and national content. Moreover, while in the past nations used to appear as the result of bringing into conformity of cultural and political identities, nowadays they may not coincide again: today, to be a member of a nation means, among other things, to be tolerant to co-citizens with other cultures.

In such a situation, what are the prospects for building promising postcolonial African states? In most of them, the main dividing line runs between cultures of the autochthonous peoples, the differences between which are not as great as between the cultures of natives and migrants - the main 'cultural actors' in the present-day Western countries. Today, this question does not have a valid response, accounting the unclear prospects of multiculturalism in the West, which continues to play the leading role in the global socio-cultural processes.

The earlier versions of most contributions to this special issue were presented as papers in the Panel 'State Building, States, and State Transformation in Africa' at the $58^{\text {th }}$ African Studies Association Annual Meeting in San Diego in November 2015. The issue logically falls into three parts.

The special issue opens with the articles in which their authors discuss the role of pre-colonial and colonial legacy political, social, and cultural legacy in nation-state-building in African countries. JeanClaude Meledje's 'Côte d'Ivoire: From Pre-Colonisation to Colonial Legacy' in which he examines the country's historical trajectories from the pre-colonial era to colonial, showing how French imposed their culture on every aspect of the Ivorian society. This article argues that despite the former French colony being independent for more than half a century, Côte d'Ivoire is still facing the challenges of the colonial years. The colonial legacy impacts various aspects of social, cultural, economic, and political development of independent Côte d'Ivoire. Meleje's article is followed by the one by Oxana Ivanchenko and Anastasia Banshchikova in which they also discuss the role of pre-colonial and colonial legacy in nation-building in Africa. They discuss it by the evidence related to a specific phenomenon they studied in Tanzanian urban setting - the mutual help groups formed by people originating from the same part of the modern state. The authors show how urbanization and mutual help practices contribute to nation-building in Tanzania. Lyubov Ya. Prokopenko analyzes the results of half a century- 
long implementation of the principle 'One Zambia - One Nation'. She shows that a threat to the country's ethnopolitical stability still persists and discusses both reasons for and possible solutions to this problem.

A number of contributions to this special issue deal with economic aspects of state-building in Africa. Chima Korieh in 'The NigeriaBiafra War, Oil and the Political Economy of Agriculture and State Induced Development Strategy in Eastern Nigeria, 1967-1995' explores the socio-economic politics in Nigeria and the challenges of state building, as well as possible solutions. Majeed A. Rahman's 'Industrial Policy: Promising Possibilities for African Economic Growth and Development' examines the different aspects of industrial policy in Africa, and their relationship with the developing African economies, how these affect state building. In 'The Developmental State Model in Ethiopia: A Path to Economic Prosperity or an Instrument of Political Repression?' Semahagn Abebe evaluates the Ethiopian doctrine of developmental state model - a new form of policy advanced by the government of Ethiopia in the aftermath of the 2005 political elections, with the aim of boosting the legitimacy of the developmental state to deliver on roads, schools and gross domestic product. His paper evaluates whether the developmental state model adopted by government achieved economic prosperity or deepened political repression. The author argues that dictators destroy the values of democracy in order to embark on self-imposed change (turn-around), which deviates from the global standard and regresses to an unsustainable paradigm.

Finally, several articles in the special issue explore the theme of democracy and state building. Oguejiofo C. P. Ezeanya discusses 'The Paradox of Human Rights and Social Justice'. The article argues that Nigeria's democracy exists as a travesty of failed state institution. The analytic thrust is built upon the premise that democratic dispensation entrenches a new paradigm of military dictatorship that continuously undermines citizens' rights and civil justice. It outlines the endemic consequences of such authority pattern as corruption, mismanagement of public funds and resources, poverty, massive unemployment, incessant conflicts and insecurity. Using Chinua Achebe's prophetic exploits in Anthills of the Savannah as an analytic tool, the author recreates Nigeria's struggles towards social liberation and recreation of a standard and socially just society. Finally, the article recommends possibilities for rebuilding sustainable democracy in Nigeria. In 'Rethinking Nigeria's Conflicts of State Building: Beyond Chinua Achebe's There Was a Country: A Personal History of Biafra', Carol Ijeoma Njoku uses Chinua Achebe's There Was a Country as a working tool to analyze the Nigerian political struggles and its struc- 
tural conflicts that undermine the projects of state building in Nigeria. The central argument is that 'Nigeria's highly centralized state structure subverts all efforts to achieve true democracy and encourages dictatorship'. A confederated or true federal state structure is recommended to restore autonomy of the states and sub-nationalities, and to achieve functional democracy in Nigeria.

The analyses provided in this work offer an insight into recurrent issues and sobering realities that confront state building in Africa ranging from education, economic and political institutions in practice to policy making. The gap created by social identities and existence of weak and shallow structures of democracy and peace building institutions are delineated with possible recommendations. The central position of the work is that the strategies for building African states cannot be oversimplified or thoughtlessly sought from the West; neither could these be attained by regrets of colonial past. They must be achieved through home-grown solutions, some of which are offered in this work. It proposes self-reliant and self-sustaining pan-African projects of state-building. The suggestions and recommendations are provided in different parts of this work. The question of state building or functional democracy transcends voting rights to participatory democracy that builds legitimate institutions for accountability, supremacy of the law, checks and balances and responsiveness to the citizen's social and economic rights. The contributors to this special issue argue that these realities become possible only when African leaders decide to 'think home', re-embrace the visions of pan-Africanism and develop workable strategies for tackling the new challenges to African states in the twenty-first century politics.

\section{REFERENCES}

Ajayi, J. A. 1982. Expectations of Independence. Daedalus 111 (2): 1-9. Ake, C. 1985. Why Africa is Not Developing. West Africa, 17 June.

Bell, D. A. 2001. The Cult of the Nation in France: Inventing Nationalism, 1680-1800. Cambridge, MA: Harvard University Press.

Bondarenko, D. M. 2014. 'Universal' Concept of Human Rights and 'African Specifics'. In Vasiliev, A. M. (ed.), African Studies in Russia. Works of the Institute for African Studies of the Russian Academy of Sciences. Yearbook 2010-2013 (pp. 75-80). Moscow: Institute for African Studies Press.

Braudel, F. 1986. Civilisation matérielle, économie et capitalisme, $X V^{e}$ XVIII siècle. Vol. 1. Les Structures du quotidian. Moscow: Progress. In Russian (Бродель, Ф. Материальная циивилиация, экономика и капитализм, XV-XVIII вв. Т. 1. Структуры повседневности. М.: Прогресс). 
Breuilly, J. 1993. Nationalism and the State. Manchester: Manchester University Press.

Breuilly, J. 2005. Nationalism and the State. In Spencer P., and Wollman H. (eds.), Nations and Nationalism: A Reader (pp. 61-73). Edinburgh: Edinburgh University Press.

Brownlee, J. 2005. Imperial Designs, Empirical Dilemmas: Why Foreign-Led State Building Fails. Stanford, CA: Center on Democracy, Development, and the Rule of Law, Stanford University Institute for International Studies.

Brownlee, J. 2010. Beyond the 'Failed State': Toward Conceptual Alternatives. European Journal of International Relations 17 (2): 303-326. doi: $10.1177 / 1354066109353137$.

Cabral, A. 1979. Unity and Struggle: Speeches and Writings of Amilcar Cabral. New York - London: Monthly Review Press.

Chabal, P., and Skalník, P. (eds.) 2010. Africanists on Africa. Current Issues. Berlin: LIT for The University of Hradec Králové.

Dann, O., and Dinwiddy, J. R. (eds.) 1988. Nationalism in the Age of the French Revolution. London; Ronceverte, WV: Hambledon Press.

David, C. 2006. Empire in Denial: The Politics of State-Building. London: Pluto Press.

Davis, T. J., and Kalu-Nwiwu, A. 2001. Education, Ethnicity and National Integration in the History of Nigeria: Continuing Problems of Africa's Colonial Legacy. The Journal of Negro History 86 (1): 1-11.

Ejiogu, E. C. 2001. The Roots of Political Instability in an Artificial 'NationState': The Case of Nigeria. International Journal of Comparative Sociology 62 (3): 323-349.

Ejiogu, E. C. 2011. The Roots of Political Instability in Nigeria: Political Evolution and Development in the Niger Basin. Farnham: Ashgate.

Fanon, F. 1963. The Wretched of the Earth. New York: Grove Press.

Fritz, V., and Menocal, A. R. 2007. Understanding State-Building from a Political Economy Perspective. An Analytical and Conceptual Paper on Processes, Embedded Tensions and Lessons for International Engagement. Report for DFID's Effective and Fragile States Teams. London: Overseas Development Institute.

Gellner, E. 1983. Nations and Nationalism. Ithaca, NY: Cornell University Press.

Jakwa, T. 2017. African Realism: Reconceptualising Notions of State Weakness in Western Thought. Conference Proceedings. 'Africa: Moving the Boundaries'. 39 ${ }^{\text {th }}$ Annual African Studies Association of Australasia and the Pacific (AFSAAP) Conference, 5-7 December 2016, The University of Western Australia (pp. 72-85). AFSAAP. URL: http://afsaap. org.au/assets/9-Tinashe-Jakwa.pdf.

Kapferer, B., and Bertelsen, B. E. (eds.) 2012. Crisis of the State. War and Social Upheaval. New York; Oxford: Berghahn Books. 
Njoku and Bondarenko / State Building, States, and State Transformation in Africa 15

Keitner, C. J. 2007. The Paradoxes of Nationalism. The French Revolution and Its Meaning for Contemporary Nation Building. Albany, NY: State University of New York Press.

Kirk-Greene, A. M. H. 1971. Crisis and Conflict in Nigeria. 2 vols. London: Oxford University Press.

Norman, M. L. 2012. The Challenges of State Building in Resource Rich Nations. Northwestern Journal of International Human Rights 10 (3): 173-190.

Nugent, P. 2011. States and Social Contracts in Africa: Time, Space and the Art of the Possible. In Horáková, H., Nugent, P., and Skalník, P. (eds.), Africa: Power and Powerlessness (pp. 22-43). Berlin: LIT for Metropolitan University Prague.

Nzongala-Ntalaja, G. 2006. Challenges to State Building in Africa. African Identities 4 (1): 71-88.

Paris, R. 1997. Peacebuilding and the Limits of Liberal Internationalism. International Security 22 (2): 54-89.

Paris, R. 2004. At War's End: Building Peace after Civil Conflict. Cambridge: Cambridge University Press.

Turner, M. D., Ayantunde, A. A., Patterson, K. P., and Patterson, E. D. 2011. Livelihood Transitions and the Changing Nature of Farmer-Herder Conflict in Sahelian West Africa. The Journal of Development Studies 47 (2): 183-206.

Turner, T. 2004. Shifting the Frame from Nation-state to Global Market. Class and Social Consciousness in the Advanced Capitalist Countries. In Chun, A. (ed.), Globalization: Critical Issues (pp. 83-119). London: Berghahn Books.

UN-OHRLLS. 2016. United Nations Office of the High Representative for the Least Developed Countries, Landlocked Developing Countries and Small Island Developing States. URL: http://www.un.org/en/development/ desa/policy/cdp/ldc/ldc_list.pdf. Accessed 23.03.2017.

Young, C. 2012. The Postcolonial State in Africa. Fifty Years of Independence, 1960-2010. Madison, WI: The University of Wisconsin Press. 